\title{
Detection of Staphylococcus aureus with an intermediate profile to vancomycin (VISA) isolate from Santa Maria, RS
}

\author{
Jaciane Baggiotto Marques ${ }^{1}$, Tanise Vendruscolo Dalmolin ${ }^{2}$, \\ Pauline Cordenonsi Bonez ${ }^{2}$, Vanessa Albertina Agertt ${ }^{2}$, \\ Marli Matiko Anraku de Campos ${ }^{2}$, Roberto Christ Vianna Santos ${ }^{1}$ \\ ${ }^{1}$ Laboratório de Microbiologia, Centro Universitário Franciscano, Santa Maria, RS, Brazil. \\ ${ }^{2}$ Laboratório de Micobacteriologia, Universidade Federal de Santa Maria, Santa Maria, RS, Brazil.
}

Submitted: May 18, 2011; Approved: July 2, 2012.

\begin{abstract}
Twenty-three isolates of Staphylococcus aureus resistant to methicillin have been analyzed, being found a clinical isolate of VISA through microdilution technique. The others techniques were unable to detect such isolates. This is the first study that shows the presence of VISA in clinical isolates in the city of Santa Maria-RS.
\end{abstract}

Key words: Staphylococcus aureus, vancomycin, microdilution.

Staphylococcus aureus is one of the most important microorganisms found in the environment as an element of the microbiota. In some conditions it can become a pathogen, causing skin infections, respiratory infections, and sepsis (Koneman et al., 2001).

The profile Vancomycin-intermediate Staphylococcus aureus (VISA) has become increasingly frequent. The identification of these strains led to the modification of the Clinical Laboratory Standards Institute (CLSI) (CLSI, $2006,2008,2009$ ) because there are flaws in the identification and therefore in the therapy with vancomycin. There is the patient exposure to unnecessary treatment, leading to therapeutic failure and increased costs associated with treatment (CLSI, 2009).

The resistance found in strains of $S$. aureus began to be isolated and identified, limiting the use of several drugs over the years (Rossi and Andreazzi, 2005). In 1960, methicillin raised, a year later resistant strains were found (Koneman 2001; Rossi and Andreazzi, 2005). With the emergence of Methicillin-resistant S. aureus (MRSA), the options for the treatment of infections by MRSA have become limited. Glycopeptides (vancomycin and teicoplanin) remained as the last resource for treatment of MRSA until recently (Cui et al., 2006).

In 1996 it was first reported the emergence of VISA and it has since then been a major concern among all health professionals. The VISA would soon spread around the world and this intermediate sensitivity to vancomycin might be associated with prolonged contact of the organism to this antimicrobial agent (Rossi and Andreazzi, 2005; Cui et al., 2006). Although some strains are of intermediate aspect, there is no clinical response to treatment with vancomycin. Even with appropriate therapy, patients do not show signs of improvement. According to Rossi et al., 2005 (Rossi and Andreazzi, 2005), all clinical isolates of VISA were recovered from patients who had treatment failure in the presence of vancomycin. Furthermore, all strains were previously reported as MRSA (Rossi and Andreazzi, 2005).

By failures in the identification of VISA, the CLSI in january 2006 changed the criteria and methodology for identification of these strains, decreasing the values of inhibition zones. To reach the current values, the method of reference applied was microdilution. After several tests with the VISA strains it was discovered that the disk diffusion, the method used in most laboratories is unable to identify strains with intermediate resistance to vancomycin, not distinguishing the strains of intermediate sensitivity. It was then discarded the possibility of using the disk diffusion technique as a method of identification of VISA, reinforcing the use of additional tests such as E-test or even the reference method, the microdilution (CLSI, 2006). 
Given the clinical importance and difficulty of detection of VISA, this study aimed to detect VISA in clinical isolates from patients hospitalized in Santa Maria-RS.

Twenty-three isolates of methicillin-resistant Staphylococcus aureus were analyzed in a clinical laboratory of analysis in the city of Santa Maria-RS in the period from August to October 2010. Being all from clinical specimens of patients hospitalized and kept (Amies or Stuart) under refrigeration. Swabs were taken from the transport and inoculated in Blood Agar culture medium and incubated at $36,5^{\circ} \mathrm{C}$ to $37^{\circ} \mathrm{C}$ for 24 hours. After this time, bacterial suspensions were prepared in sterile saline to obtain a turbidity of $0.5 \mathrm{Mac}$ Farland scale, equivalent to $1.5 \times 10^{8} \mathrm{cfu} / \mathrm{mL}$.

The methods recommended by CLSI 2008 (disk diffusion) and CLSI 2009 (microdilution) and the technology of E-test (Biomérieux, 2011) were applied. To carry out the techniques of disk diffusion and E-test were used Petri dishes with Mueller-Hinton (Merck ${ }^{\circledR}$ ). Swabs after dipped in bacterial suspension were seeded, being implanted disks and E-test strips. For the microdilution, the medium was Mueller-Hinton broth in microdilution plates with the bacterial suspension and increasing concentrations of vancomycin and incubated for 24 hours at $35{ }^{\circ} \mathrm{C} \pm 2{ }^{\circ} \mathrm{C}$. The microdilution followed the concentrations recommended by the CLSI in 2009 on the plates and the tests were performed in quintuplicate (CLSI 2008, 2009).

The Table 1 shows the sites of isolation of strains of Methicillin-resistant Staphylococcus aureus from hospitalized patients in Santa Maria-RS (Table 1).

According to Swenson et al., 2008 (Swenaon et al., 2009), disk diffusion is ineffective in detecting VISAs and frequently way is proving to be a weak test. It is highly likely, however, that such failures are widely under-reported, since most of the laboratories in the past would have considered these strains as "susceptible" to vancomycin leading to failure with the use of antimicrobials; it means that the laboratory mistake is strongly associated with treatment failure (Tenover and Mollering, 2007; Swenaon et al., 2009).

Currently there is a growing number of VISA mainly found in countries like Japan, United States, France, Britain and Germany, where its incidence is increasing causing a significant spread occurs worldwide and it is necessary more control done by surveillance systems and Centers for Disease Control and Prevention, which have increasingly received reports of isolation of VISA (Tenover et al., 2006; Gyungtae et al., 2010)

Most isolates with reduced susceptibility to vancomycin appear to have developed from pre-existing infections with MRSA after prolonged treatment with vancomycin are insulated with vancomycin intermediate profile (Tenover et al., 2006).

In France, studies performed in a hospital show a prevalence of $0.07 \%$ VISA. In the U.S.A., the prevalence increased from $0.3 \%$ to $2.3 \%$ in just 22 years and in Asia,
Table 1 - Results of disk diffusion, E-test, and microdilution.

\begin{tabular}{|c|c|c|c|}
\hline Strain number & Disk difusion & E-test & Microdilution \\
\hline 1 & $20 \mathrm{~mm}$ & $1.0 \mu \mathrm{g} / \mathrm{mL}$ & $2 \mu \mathrm{g} / \mathrm{mL}$ \\
\hline 2 & $26 \mathrm{~mm}$ & $1.0 \mu \mathrm{g} / \mathrm{mL}$ & $2 \mu \mathrm{g} / \mathrm{mL}$ \\
\hline 3 & $21 \mathrm{~mm}$ & $1.0 \mu \mathrm{g} / \mathrm{mL}$ & $2 \mu \mathrm{g} / \mathrm{mL}$ \\
\hline 4 & $20 \mathrm{~mm}$ & $1.0 \mu \mathrm{g} / \mathrm{mL}$ & $2 \mu \mathrm{g} / \mathrm{mL}$ \\
\hline 5 & $22 \mathrm{~mm}$ & $0.75 \mu \mathrm{g} / \mathrm{mL}$ & $2 \mu \mathrm{g} / \mathrm{mL}$ \\
\hline 6 & $22 \mathrm{~mm}$ & $1.0 \mu \mathrm{g} / \mathrm{mL}$ & $2 \mu \mathrm{g} / \mathrm{mL}$ \\
\hline 7 & $26 \mathrm{~mm}$ & $0.50 \mu \mathrm{g} / \mathrm{mL}$ & $4 \mu \mathrm{g} / \mathrm{mL}$ \\
\hline 8 & $20 \mathrm{~mm}$ & $1.0 \mu \mathrm{g} / \mathrm{mL}$ & $2 \mu \mathrm{g} / \mathrm{mL}$ \\
\hline 9 & $20 \mathrm{~mm}$ & $1.5 \mu \mathrm{g} / \mathrm{mL}$ & $2 \mu \mathrm{g} / \mathrm{mL}$ \\
\hline 10 & $20 \mathrm{~mm}$ & $1.0 \mu \mathrm{g} / \mathrm{mL}$ & $2 \mu \mathrm{g} / \mathrm{mL}$ \\
\hline 11 & $18 \mathrm{~mm}$ & $0.75 \mu \mathrm{g} / \mathrm{mL}$ & $2 \mu \mathrm{g} / \mathrm{mL}$ \\
\hline 12 & $21 \mathrm{~mm}$ & $1.0 \mu \mathrm{g} / \mathrm{mL}$ & $2 \mu \mathrm{g} / \mathrm{mL}$ \\
\hline 13 & $20 \mathrm{~mm}$ & $1.5 \mu \mathrm{g} / \mathrm{mL}$ & $2 \mu \mathrm{g} / \mathrm{mL}$ \\
\hline 14 & $22 \mathrm{~mm}$ & $1.5 \mu \mathrm{g} / \mathrm{mL}$ & $2 \mu \mathrm{g} / \mathrm{mL}$ \\
\hline 15 & $18 \mathrm{~mm}$ & $1.0 \mu \mathrm{g} / \mathrm{mL}$ & $2 \mu \mathrm{g} / \mathrm{mL}$ \\
\hline 16 & $16 \mathrm{~mm}$ & $0.75 \mu \mathrm{g} / \mathrm{mL}$ & $2 \mu \mathrm{g} / \mathrm{mL}$ \\
\hline 17 & $18 \mathrm{~mm}$ & $0.50 \mu \mathrm{g} / \mathrm{mL}$ & $2 \mu \mathrm{g} / \mathrm{mL}$ \\
\hline 18 & $22 \mathrm{~mm}$ & $1.5 \mu \mathrm{g} / \mathrm{mL}$ & $2 \mu \mathrm{g} / \mathrm{mL}$ \\
\hline 19 & $18 \mathrm{~mm}$ & $0.38 \mu \mathrm{g} / \mathrm{mL}$ & $2 \mu \mathrm{g} / \mathrm{mL}$ \\
\hline 20 & $20 \mathrm{~mm}$ & $1.0 \mu \mathrm{g} / \mathrm{mL}$ & $2 \mu \mathrm{g} / \mathrm{mL}$ \\
\hline 21 & $18 \mathrm{~mm}$ & $0.50 \mu \mathrm{g} / \mathrm{mL}$ & $2 \mu \mathrm{g} / \mathrm{mL}$ \\
\hline 22 & $20 \mathrm{~mm}$ & $0.75 \mu \mathrm{g} / \mathrm{mL}$ & $2 \mu \mathrm{g} / \mathrm{mL}$ \\
\hline 23 & $19 \mathrm{~mm}$ & $0.75 \mu \mathrm{g} / \mathrm{mL}$ & $2 \mu \mathrm{g} / \mathrm{mL}$ \\
\hline $\begin{array}{l}\text { Quality control } \\
\text { ATCC } 29213\end{array}$ & $19 \mathrm{~mm}$ & $0.5-2 \mu \mathrm{g} / \mathrm{mL}$ & $2 \mu \mathrm{g} / \mathrm{mL}$ \\
\hline
\end{tabular}

countries like Thailand have rates of $0.8 \%$ and Japan $0.24 \%$ (Adam et al., 2010 Gyungtae et al., 2010).

In Brazil, in the state of Minas Gerais, in the city of Uberlandia a few cases was found of patients colonized with MRSA. With prolonged use of vancomycin among these patients, there was the isolation of a VISA strain (Melo et al., 2005).

In this study, a total of 23 strains tested by disk diffusion test, microdilution, and E-test one isolated VISA were detected, according to Table 1. Disk diffusion and E-test methods were unable to detect VISA, collaborating with other studies (Wang et al., 2006). Therefore it is necessary to encourage clinical laboratories to use microdilution technique for the detection of VISA, as recommended by CLSI 2009 (CLSI, 2009).

This is the first study that shows the presence of VISA in clinical isolates in the city of Santa Maria-RS, Brazil. We detected a strain of vancomycin intermediate, showing the presence of this microorganism in our midst, as it happens in the U.S.A., Japan, France, and Germany where there is an increasing number of strains with intermediate vanco- 
mycin profile. Given the importance of this clinical VISA isolate, becomes important then surveillance studies, thus preventing the emergence of VISA.

\section{References}

Adam HJ, Louie L, Watt C, Gravel D, Bryce E, Loeb M, Matlow A, McGeer A, Mulvey MR, Simor AE (2010) Detection and characterization of heterogeneous vancomycin-intermediate Staphylococcus aureus isolates in Canada: results from the Canadian Nosocomial Infection Surveillance Program, 1995-2006. Antimicrob Ag Chem 54:945-949.

Biomérieux E test. Summary of E test ${ }^{\circledR}$ performance, interpretive Criteria and Quality Control Ranges. http://www.abbiodisk.com/pdf/pi/75002290.pdf. Accessed September 20, 2011.

Cui L, Iwamoto A, Lian J, Neoh H, Mmaruyama T, Horikawa Y, Hiramatsu K (2006) Novel mechanism of antibiotic resistance originating in vancomycin-intermediate Staphylococcus aureus. Antimicrob Agents Chemother 50:428-238.

CLSI - Clinical and Laboratory Standards Institute. (2006). Performance standards for antimicrobial susceptibility testing. Sixteenth Informational Supplement. Document M100-S16, Wayne,PA.

CLSI-Clinical Laboratory Standards Institute. (2008). Performance standards for antimicrobial susceptibility testing. Eigtheenth Informational Supplement. Document M100S18, Wayne, PA.

CLSI - Clinical Laboratory Standards Institute. (2009). Performance standards for antimicrobial susceptibility testing; Nineteenth Informational Supplement. Document M100S19, Wayne, PA.
Gyungtae C, Cha J, Han S, Jang H, Lee K, Yoo J, Yoo J, Kim H, Eun S, Kim B, Park O, Lee Y (2010) Nationwide surveillance Study of vancomycin-intermediate Staphylococcus aureus strains in Korean Hospitals from 2001 to 2006. J Microbiol Biotec 20:637-642.

Koneman EW, Allen SD, Janda WM, Schereckenberger PC, Winn WC (2001) Diagnóstico Microbiológico: Texto e Atlas Colorido. MEDSI, São Paulo, 1465 pp.

Melo GB, Melo MC, Gama AP, Carvalho KS, Jesus TC, Bonetti AM, Gontijo PPF (2005) Analysis of the genetic diversity of vancomycin-resistant Staphylococcus aureus. Braz J Microbiol 36:126-130.

Rossi F, Andreazzi DB (2005) Resistência Bacteriana: Interpretando o Antibiograma. Atheneu, São Paulo, 118 pp.

Swenaon JM, Anderson K F, Lonsway DR, Thompson A, Mcallister CK, Limbago BM, Carey RB, Tenover FC, Patel JB (2009) Accuracy of commercial and reference susceptibility testing methods for detecting vancomycin-intermediate Staphylococcus aureus. J Clin Microbiol 47:20132017.

Tenover FC, Moellering RCJ (2007) The rationale for revising the clinical and laboratory standards institute vancomycin minimal inhibitory concentration interpretive criteria for Staphylococcus aureus. Clin Infect Dis 44:1208-1215.

Tenover FC, Biddle JW, Lancaster MV (2006) Increasing resistance to vancomycin and other glycopeptides in Staphylococcus aureus. Emerg Infect Dis 7:327-332.

Wang G, Hindler JF, Ward KW, Bruckner DA (2006) Increased vancomycin MICs for Staphylococcus aureus clinical isolates from a University Hospital during a 5-year period. J Clin Microbiol 44:3883-3886.

All the content of the journal, except where otherwise noted, is licensed under a Creative Commons License CC BY-NC. 